\title{
Expression of HuR, COX-2, and survivin in lung cancers; cytoplasmic HuR stabilizes cyclooxygenase-2 in squamous cell carcinomas
}

\author{
Gou Young Kim${ }^{1}$, Sung-Jig $\operatorname{Lim}^{1}$ and Youn Wha Kim² \\ ${ }^{1}$ Department of Pathology, Kyung Hee University Hospital at Gangdong, School of Medicine, Kyung Hee \\ University, Seoul, South Korea and ${ }^{2}$ Department of Pathology, Kyung Hee Medical Center, School of \\ Medicine, Kyung Hee University, Seoul, South Korea
}

\begin{abstract}
Hu antigen $R$ (HuR) is a member of the human family of embryonic-lethal, abnormal vision-like proteins, which serves as an mRNA-binding protein. In the cytoplasm, HuR can stabilize the mRNA of cyclooxygenase-2 (COX-2), an enzyme that catalyses the synthesis of prostaglandins and is associated with promotion of carcinogenesis and tumor cell resistance to apoptosis. Intracellular (cytoplasmic and nuclear) localization of survivin has a prognostic significance as an apoptosis inhibitor and a regulator of cell division in tumors. Patients with 151 squamous cell carcinomas and 93 adenocarcinomas underwent lobectomy or pneumonectomy with hilar and mediastinal lymph node sampling. Paraffin-embedded tumor sections were retrieved for evaluation of nuclear and cytoplasmic staining of survivin and HuR, and cytoplasmic staining of COX-2. In squamous cell carcinomas, COX-2 expression was correlated with a difference of survivin (cytoplasmicnuclear; $P=0.004)$, cytoplasmic HuR $(P=0.018)$, total HuR (cytoplasmic + nuclear; $P=0.009$ ), and difference of HuR $(P=0.020)$. COX-2 was inversely correlated with nuclear survivin $(P=0.006)$. In a univariate analysis by log-rank test, survival was associated with cytoplasmic survivin (adenocarcinoma, $P<0.001$; squamous cell carcinoma, $P=0.005$ ), difference of survivin (adenocarcinoma, $P<0.001$; squamous cell carcinoma, $P=0.014$ ), and COX-2 (squamous cell carcinoma, $P=0.001$ ). Survival was inversely associated with nuclear survivin (adenocarcinoma, $P=0.006$, squamous cell carcinoma, $P=0.014$ ). In a multivariate survival analysis, cytoplasmic survivin (adenocarcinoma, $P=0.002$; squamous cell carcinoma, $P=0.015$ ) and COX-2 (squamous cell carcinoma, $P=0.020$ ) were determined as independent prognostic factors. Cytoplasmic HuR expression is associated with COX-2 expression in squamous cell carcinomas. The expression of COX-2 in squamous cell carcinomas, and cytoplasmic survivin in adenocarcinomas and squamous cell carcinomas could be useful independent prognostic markers.
\end{abstract}

Modern Pathology (2011) 24, 1336-1347; doi:10.1038/modpathol.2011.90; published online 13 May 2011

Keywords: apoptosis regulatory proteins; cyclooxygenase 2; immunohistochemistry; lung neoplasms; nuclear export signals; RNA-binding proteins

HuR (ELAVL1, the HUGO Gene Nomenclature Committee (HGNC)-approved official symbol for $\mathrm{HuR}$ ) is an mRNA binding protein that belongs to

Correspondence: Professor Gou Young Kim, MD, Department of Pathology, Kyung Hee University Hospital at Gangdong, School of Medicine, Kyung Hee University, 149, Sangil-dong, Gangdong-gu, Seoul, 134-727, South Korea.

E-mail: pathogen@medimail.co.kr

Received 12 October 2010; revised 21 March 2011; accepted 21 March 2011; published online 13 May 2011 the embryonic-lethal, abnormal vision-like protein family. ${ }^{1}$ It binds to labile transcripts containing AU-rich elements, such as mRNAs for proto-oncogenes, cytokines, and cytokine-response genes. HuR is predominantly present in the nucleus where it can bind to target mRNAs; whereas in the cytoplasm, it stabilizes these messages. ${ }^{2} \mathrm{HuR}$ can stabilize cyclooxygenase-2 (COX-2) mRNA, leading to an increase in COX-2 expression (Figure 1). ${ }^{3}$ There are some reports showing that the constitutive overexpression of COX-2 in ovarian and colon 


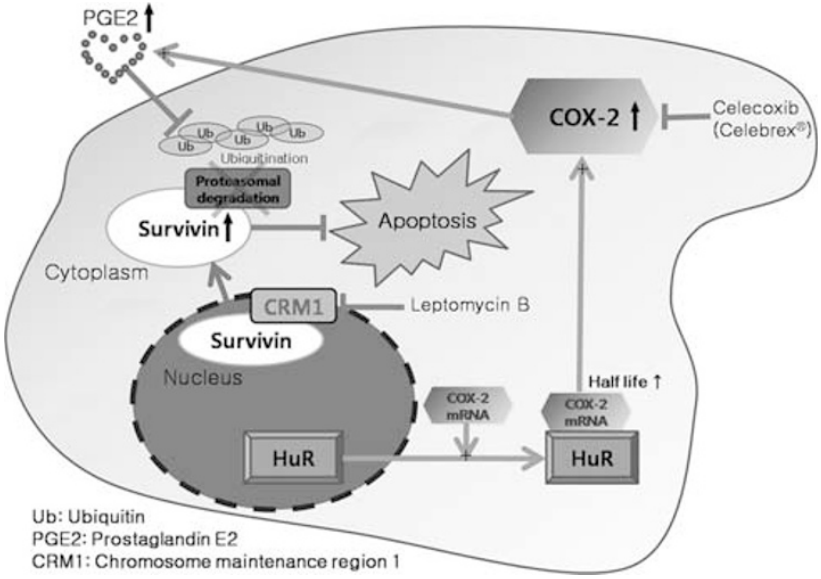

Figure 1 Diagram of HuR, COX-2, and survivin. HuR can bind to COX-2 mRNAs and stabilizes COX-2 mRNA, leading to an increase in COX-2 expression. COX-2 overexpression modulates survivin ubiquitination by a production of the COX-2 metabolite $\mathrm{PGE}_{2}$. Survivin is detected in either the nucleus or the cytoplasm of cancer cells, or both subcellular pools. The nuclear export receptor Crm1 is involved in intracellular localization of survivin. Survivin is able to bind caspases, thus preventing apoptosis.

cancers is the result of HuR overexpression, and that this process has an important role in the carcinogenesis of several cancers. ${ }^{3,4}$

COXs are rate-limiting enzymes in prostanoid synthesis, which convert arachidonic acid into prostaglandin (PG) H2, a substrate for specific PG synthases. ${ }^{5}$ Two isoforms of COX have been isolated and characterized: ubiquitously expressed COX-1 and inducible COX-2. ${ }^{6}$ Studies of human cancers have revealed frequent overexpression of COX-2 in a variety of different malignancies, including lung cancers. ${ }^{7-10}$ COX-2 (PTGS2, HGNC-approved official symbol for COX-2) and its enzymatic product $\mathrm{PGE}_{2}$ have critical roles in inflammation and carcinogenesis, such as epithelial cell growth, invasion, and the promotion of tumor cell resistance to apoptosis (Figure 1). ${ }^{11,12}$

Survivin (BIRC5, HGNC-approved official symbol for survivin), a member of inhibitors of the apoptosis (IAP) gene family, is a $16.5-\mathrm{kD}$ protein that inhibits apoptosis and regulates cell division. The expression of survivin is undetectable or found at very low levels in normal tissues, whereas it is found at high levels in embryonic and fetal tissues, and also various malignancies, including lung cancer. ${ }^{13}$ Survivin is detected in either the nucleus or the cytoplasm of cancer cells, or both. ${ }^{14}$ Recent evidence shows that the direct interaction of survivin with the nuclear export receptor Crm1 is critically involved in the intracellular localization and cancer-relevant functions of survivin. ${ }^{15-18}$ Survivin is also able to bind caspases, thus preventing their activation (Figure 1). ${ }^{19}$ Suppression of survivin expression leads to increased caspase-3 activation and apoptosis, as well as mitosis deregulation and sensitization to anticancer drugs. ${ }^{20,21}$

COX-2-dependent expression of survivin was previously reported as a critical factor in apoptosis resistance in non-small cell lung cancer cell lines. ${ }^{22}$ However, the mechanism by which COX-2 exerts its cytoprotective effects is not completely understood. The relationship of nuclear versus cytoplasmic expression of survivin with apoptosis and the expression of HuR-related COX-2 expression is not well characterized in primary human lung cancers. ${ }^{23-31}$

In this study, we evaluated the expression of survivin, COX-2, and HuR, and subcellular localization of survivin and HuR in sets of pulmonary adenocarcinomas and squamous cell carcinomas patients, in relation to clinicopathologic parameters and survival. In addition, we investigated the relation of survivin, COX-2, and HuR expression.

\section{Materials and methods}

\section{Patients and Specimens}

A total of 244 patients with primary pulmonary adenocarcinomas and squamous cell carcinomas, diagnosed and operated on at Kyung Hee Medical Center, College of Medicine, Kyung Hee University, between 1985 and 2005, were included in this study. Within that sample were 151 squamous cell carcinomas and 93 adenocarcinomas. Patients underwent surgical resection with hilar and mediastinal lymph node sampling. Certain clinical and pathologic parameters were retrospectively summarized from the patient's file, including details on age, gender, histopathologic type, tumor differentiation, primary tumor, regional lymph node, distant metastasis and pathologic stage, and follow-up (Table 1). The mean of patient age at surgery was 62 years (range 35 to 81). Standard hematoxylin and eosin (H\&E)-stained sections of the formalin-fixed, paraffin-embedded tumor tissues were reviewed by two pathologists (GY Kim and SJ Lim) to confirm the histologic diagnosis according to the current WHO classification. ${ }^{32}$ Pathologic stage of disease in patients was determined according to the criteria set forth by the American Joint Committee on Cancer. ${ }^{33}$

\section{Tissue Microarray}

The paraffin-embedded tissues were sampled from archived conventional tissue blocks. Three areas of tumor were chosen by two surgical pathologists (GYK and SJL). The tissue microarrays were constructed with an AccuMax Array (ISU ABXIS/ PeTagen) by sampling the three representative areas $(2.0 \mathrm{~mm}$ in diameter) of the original tumor, and transferring them into a new array block.

\section{Immunohistochemistry}

Paraffin-embedded material was available in a set of 244 individual tumors for evaluation of nuclear and cytoplasmic staining of survivin and HuR, and 
Table 1 Clinicopathologic characteristics of 93 ADCs and 151 SCCs of the lung

\begin{tabular}{|c|c|c|c|c|}
\hline \multirow[t]{2}{*}{ Characteristics } & \multicolumn{2}{|c|}{$A D C$} & \multicolumn{2}{|c|}{$S C C$} \\
\hline & $\mathrm{n}=93$ & $\%$ & $\mathrm{n}=151$ & $\%$ \\
\hline \multicolumn{5}{|l|}{ Gender } \\
\hline Female & 40 & 43 & 15 & 10 \\
\hline Male & 53 & 57 & 136 & 90 \\
\hline \multicolumn{5}{|l|}{ Age (years) } \\
\hline Range & $35-81$ & & $37-81$ & \\
\hline Mean (s.d.) & $61.9 \pm 9.4$ & & $61.9 \pm 8.6$ & \\
\hline Median & 64 & & 62 & \\
\hline \multicolumn{5}{|l|}{ Differentiation } \\
\hline Well & 9 & 10 & 8 & 5 \\
\hline Moderate & 66 & 71 & 124 & 82 \\
\hline Poor & 18 & 19 & 19 & 13 \\
\hline \multicolumn{5}{|l|}{ Primary tumor } \\
\hline T1a & 10 & 11 & 9 & 6 \\
\hline T1b & 15 & 16 & 15 & 10 \\
\hline T2a & 37 & 40 & 55 & 36 \\
\hline $\mathrm{T} 2 \mathrm{~b}$ & 10 & 11 & 25 & 17 \\
\hline T3 & 16 & 17 & 35 & 23 \\
\hline $\mathrm{T} 4$ & 5 & 5 & 12 & 8 \\
\hline \multicolumn{5}{|l|}{ Regional LN } \\
\hline No & 46 & 50 & 90 & 60 \\
\hline N1 & 17 & 18 & 37 & 24 \\
\hline N2 & 30 & 32 & 24 & 16 \\
\hline N3 & 0 & 0 & 0 & 0 \\
\hline \multicolumn{5}{|l|}{ Distant metastasis } \\
\hline Mo & 90 & 97 & 151 & 100 \\
\hline M1a & 3 & 3 & 0 & 0 \\
\hline M1b & 0 & 0 & 0 & 0 \\
\hline \multicolumn{5}{|l|}{ Pathologic stage } \\
\hline IA & 18 & 19 & 17 & 11 \\
\hline IB & 18 & 19 & 34 & 23 \\
\hline IIA & 9 & 10 & 26 & 17 \\
\hline IIB & 11 & 12 & 30 & 20 \\
\hline IIIA & 31 & 33 & 42 & 28 \\
\hline IIIB & 3 & 3 & 2 & 1 \\
\hline IV & 3 & 3 & 0 & 0 \\
\hline
\end{tabular}

ADC, adenocarcinoma; LN, lymph node; SCC, squamous cell carcinoma.

cytoplasmic staining of COX-2. Immunohistochemical staining was performed using $4-\mu \mathrm{m}$-thick tissue sections from the tissue microarray blocks and a Bond Polymer Intense Detection System (VisionBioSystems, Vic, Australia) according to the manufacturer's instructions, with minor modifications. In brief, each formalin-fixed and paraffin-embedded section was deparaffinized with Bond Dewax Solution (VisionBioSystems), and subjected to antigen retrieval using Bond ER Solution (VisionBioSystems) at $100^{\circ} \mathrm{C}$ for $30 \mathrm{~min}$. The endogenous peroxidase was subsequently quenched by incubation with hydrogen peroxide for $5 \mathrm{~min}$. The sections were then incubated for $15 \mathrm{~min}$ at room temperature, with anti-survivin (NB500-201; 1:1000; Novus, Littleton, CO, USA), anti-COX-2 (RM-9121-R7;
1:200; LabVision, Fremont, CA, USA), and antiHuR antibodies (39-0600; 1:300; Zymed, Carlsbad, CA, USA), using a biotin-free polymeric horseradish peroxidase-linker antibody conjugate system in a Bond-maX automatic slide stainer (VisionBioSystems), and visualized using a 3.3-diaminobenzidine (DAB) solution (1 mM DAB, $50 \mathrm{mM}$ Tris-HCL buffer (pH 7.6), and $0.006 \% \quad \mathrm{H}_{2} \mathrm{O}_{2}$ ). The slides were counterstained with hematoxylin. Negative control slides without a primary antibody were included for each staining.

\section{Immunohistochemical Evaluation}

Staining was assessed in five high-powered fields at $\times 400$ magnification. Survivin and HuR immunoreactivity were evaluated semiquantitatively on the basis of staining intensity and proportion. The stained tumor tissues were scored blindly with respect to clinical patient by two investigators (GY Kim and SJ Lim). The cytoplasmic and nuclear staining patterns of survivin and HuR were evaluated separately. The proportion of staining was scored on a scale from 0 to 3 as follows: diffuse, $>50 \%$ positive (score 3); regional, $25 \%$ to $50 \%$ positive (score 2); focal, 5 to $25 \%$ positive (score 1 ); negative (score 0 ). In addition, the intensity of staining was scored from 0 to 3 ( 0 , absent; 1 , weak; 2 , moderate; 3 , intense). The overall immunoreactive score for each sample was determined by multiplying the two individual scores. In order to describe the intracellular localization and expression levels of survivin and HuR in the tumors, total immunoreactive score (cytoplasmic immunoreactive score plus nuclear immunoreactive score) and the difference in immunoreactive score (cytoplasmic immunoreactive score minus nuclear immunoreactive score) were determined. Cytoplasmic and nuclear immunoreactive score were also further simplified in positive and negative cases as follows: moderate diffuse, intense regional, and intense diffuse were considered positive (high expression), and moderate regional, moderate focal, and all three proportions of weak staining were considered negative (low expression). Total immunoreactive score was divided into positive $(\geq 12)$ and negative $(<12)$. The difference in immunoreactive score was divided into positive $(>0)$ and negative $(\leq 0)$. The cut-off value was defined by ROC curve. COX-2 staining was scored as positive $(>10 \%)$, and negative (0 to $10 \%)$.

\section{Statistical Analysis}

The remaining parameters were categorized as follows: age $(<62$ vs $\geq 62)$, histological grade (well to moderate vs poor), primary tumor (T1-T2 vs T3-T4), regional lymph node (No vs N1-N2), and pathologic stage (I-II vs III-IV). The relationships between the immunoreactive score of survivin, 
COX-2, HuR, and the clinicopathologic parameters were investigated using Pearson's $\chi^{2}$-test. Correlations of HuR vs COX-2, and COX-2 vs survivin were evaluated by the Spearman's rank correlation coefficient. Overall survival was calculated from the date of diagnosis to the date of death or last follow-up. Patients who were alive were censored at the time of their last follow-up visit. Deaths due to intercurrent causes were censored. Univariate analysis was performed, and the significance of differences in survival between the groups was determined using the log rank test. Cumulative survival curves and overall survival for groups were computed according to the Kaplan-Meier method. To evaluate the hazard ratios and the independent prognostic relevance, multivariate analysis using the Cox proportional hazard model was performed using the following covariates: sex, age, primary tumor, regional lymph node, distant metastasis, pathologic stage, and survivin, COX-2, and HuR levels, coded as they were in the univariate analysis. All tests of significance were two-sided, and differences were considered statistically significant at $P$-value of $<0.05$. Data analyses were performed using SPSS 15.0 (Chicago, IL, USA).

\section{Results}

\section{Expressions of Survivin, COX-2, and HuR}

As is shown in Table 2 and Figure 2, cytoplasmic, nuclear, difference, and the total survivin immunoreactivity were positive in 67 (72\%), 62 (67\%), 32 $(34 \%)$, and $52(56 \%)$ adenocarcinomas, respectively. In squamous cell carcinomas, cytoplasmic, nuclear, difference, and the total survivin immunoreactivity were positive in 116 (77\%), 134 (89\%), $18(12 \%)$, and $112(75 \%)$, respectively. COX-2 immunoreactivity was positive in $79(85 \%)$ adenocarcinomas and 87 (58\%) squamous cell carcinomas. Cytoplasmic, nuclear, difference, and the total HuR immunoreactivity were positive in 62 (67\%), 87 (94\%), 12 (13\%), and $65(70 \%)$ adenocarcinomas, and $103(68 \%)$, 137 (91\%), 24 (16\%), and 115 (76\%) squamous cell carcinomas, respectively.

\section{Association of HuR, COX-2, and Survivin Expression with Clinicopathologic Variables}

As is shown in Table 2, cytoplasmic survivin was found to be significantly increased in adenocarcinomas exhibiting poor differentiation $(P=0.024)$ and higher stage of primary tumor $(P=0.030)$, and in male patients with squamous cell carcinomas $(P=0.015)$. Nuclear survivin expression of adenocarcinomas was found to be significantly increased in older patients $(P=0.015)$, in patients with well differentiation $(P=0.042)$ and a lower status of primary tumor $(P=0.015)$. The difference in survivin expression of adenocarcinomas was found to be significantly increased in poor differentiation $(P=0.036)$. Nuclear $(P<0.001)$ and total $(P=0.003)$ survivin expression were found to be significantly increased in squamous cell carcinomas. The difference of survivin $(P<0.001)$ and COX-2 $(P<0.001)$ expression were found to be significantly in creased in adenocarcinomas. Cytoplasmic HuR expression was found to be significantly increased in squamous cell carcinomas exhibiting poor differentiation $(P=0.044)$. Nuclear $(P=0.035)$ and total $(P=0.009) \mathrm{HuR}$ expression were found to be significantly increased in male patients with squamous cell carcinomas.

\section{Correlations of HuR vs COX-2, and COX-2 vs Survivin Expression}

In squamous cell carcinomas, cytoplasmic $\mathrm{HuR}$ ( $\rho=0.192, \quad P=0.018)$, the difference in HuR $(\rho=0.190, P=0.020)$, and total HuR $(\rho=0.212$, $P=0.009)$, were positively correlated with COX-2 expression. COX-2 expression was positively correlated with the difference in survivin ( $\rho=0.223, P=0.004)$, and inversely correlated with nuclear survivin $(\rho=-0.221, P=0.006$; Table 3 and Figure 3).

\section{Prognostic Value of Survivin, COX-2, and HuR Expression}

The median survival of patients was determined as $53 \pm 7.0$ (adenocarcinoma) and $84 \pm 23.3$ months (squamous cell carcinoma) (Table 4). At the end of the study, 52 (56\%) (adenocarcinoma) and 83 (55\%) (squamous cell carcinoma) patients had died. The cumulative 5-year survival rate was 50\% (adenocarcinoma) and $64 \%$ (squamous cell carcinoma). In a univariate analysis by log-rank test, primary tumor (T1-T2 vs T3-T4) (adenocarcinoma, $P<0.001$; squamous cell carcinoma, $P=0.001$ ), regional lymph node (N0 vs N1-N2) (adenocarcinoma, $P=0.040$; squamous cell carcinoma, $P=0.001)$, distant metastasis (M0 vs M1) (adenocarcinoma, $P=0.028$ ), pathologic stage (I-II vs III-IV) (adenocarcinoma, $P=0.003$; squamous cell carcinoma, $P<0.001$ ), cytoplasmic survivin (adenocarcinoma, $P<0.001$; squamous cell carcinoma, $P=0.005)$, the difference in survivin (adenocarcinoma, $P<0.001$; squamous cell carcinoma, $P=0.014$ ), and COX-2 levels (squamous cell carcinoma, $P=0.001$ ) were associated with shorter survival rate, whereas nuclear survivin was associated with a longer survival rate (adenocarcinoma, $P=0.001$, squamous cell carcinoma, $P=0.050 ;$ Table 4). No significant correlation was found between HuR expression and survival. The overall survival for patients was statistically significant when described by Kaplan-Meier curves (Figure 4). In multivariate survival analysis using Cox proportional hazards model, cytoplasmic survivin (adenocarcinoma, $P=0.002$; squamous cell 
Table 2 Correlations between expressions of survivin, Cox-2, and HuR with clinicopathologic characteristics in 93 ADCs and 151 SCCs of the lung

\begin{tabular}{|c|c|c|c|c|c|c|c|c|c|c|c|c|c|c|c|c|c|c|}
\hline \multirow{3}{*}{$\begin{array}{l}\text { Characteristics } \\
\text { Histology }\end{array}$} & \multicolumn{8}{|c|}{ Survivin ( $\%$ within factor) } & \multirow{2}{*}{\multicolumn{2}{|c|}{$\frac{\text { COX-2 (\% within factor })}{\text { Positive }}$}} & \multicolumn{8}{|c|}{ HuR (\% within factor) } \\
\hline & \multicolumn{2}{|c|}{$C$ (high) } & \multicolumn{2}{|c|}{$N$ (high) } & \multicolumn{2}{|c|}{$C-N>0$} & \multicolumn{2}{|c|}{$C+N \geq 12$} & & & \multicolumn{2}{|c|}{$C$ (high) } & \multicolumn{2}{|c|}{$N$ (high) } & \multicolumn{2}{|c|}{$C-N>0$} & \multicolumn{2}{|c|}{$C+N \geq 12$} \\
\hline & $\begin{array}{c}\text { ADC } \\
67(72)\end{array}$ & $\begin{array}{c}\text { SCC } \\
116(77)\end{array}$ & $\begin{array}{r}\text { ADC } \\
62(67)\end{array}$ & $\begin{array}{c}\text { SCC } \\
134(89)\end{array}$ & $\begin{array}{c}\text { ADC } \\
32(34)\end{array}$ & $\begin{array}{c}\text { SCC } \\
18(12)\end{array}$ & $\begin{array}{c}\text { ADC } \\
52(56)\end{array}$ & $\begin{array}{c}\text { SCC } \\
112(74)\end{array}$ & $\begin{array}{r}\text { ADC } \\
79(85)\end{array}$ & $\begin{array}{c}\text { SCC } \\
87(58)\end{array}$ & $\begin{array}{c}\text { ADC } \\
62(67)\end{array}$ & $\begin{array}{c}\text { SCC } \\
103(68)\end{array}$ & $\begin{array}{r}\text { ADC } \\
87(94)\end{array}$ & $\begin{array}{c}\text { SCC } \\
137(91)\end{array}$ & $\begin{array}{c}\mathrm{ADC} \\
12(13)\end{array}$ & $\begin{array}{c}\text { SCC } \\
24(16)\end{array}$ & $\begin{array}{c}\mathrm{ADC} \\
65(70)\end{array}$ & $\begin{array}{c}\text { SCC } \\
115(76)\end{array}$ \\
\hline$P$-value $\left(\chi^{2}\right)$ & & 403 & $<0$ & .001 & $<\mathbf{0}$. & 001 & & 003 & & & & 802 & 0.4 & 435 & & 522 & & 280 \\
\hline \multicolumn{19}{|l|}{ Gender } \\
\hline Female & $29(73)$ & $8(53)$ & $25(63)$ & $13(87)$ & $17(43)$ & $0(0)$ & $21(53)$ & $8(53)$ & $34(85)$ & $6(40)$ & $28(70)$ & $7(47)$ & $38(95)$ & $11(73)$ & $4(10)$ & $2(13)$ & $28(70)$ & $7(47)$ \\
\hline Male & $37(72)$ & $108(79)$ & $37(70)$ & 121 (89) & $15(28)$ & $18(13)$ & 31 (59) & $104(77)$ & $45(85)$ & $81(60)$ & $34(64)$ & $96(71)$ & $49(93)$ & $126(93)$ & $8(15)$ & $22(16)$ & $37(70)$ & $108(79)$ \\
\hline$P$-value $\left(\chi^{2}\right)$ & 0.932 & 0.046 & 0.459 & 0.678 & 0.154 & 0.218 & 0.565 & 0.065 & 0.990 & 0.146 & 0.554 & 0.079 & 0.696 & 0.035 & 0.468 & 1.000 & 0.984 & 0.009 \\
\hline \multicolumn{19}{|l|}{ Age } \\
\hline$<62$ & (71) & $56(77)$ & $18(51)$ & $63(86)$ & $16(46)$ & $10(14)$ & $16(46)$ & $53(73)$ & $29(83)$ & 37 (51) & $21(60)$ & $51(70)$ & $31(89)$ & $67(92)$ & $5(14)$ & 10 & $22(63)$ & $57(78)$ \\
\hline$\geq 62$ & $42(72)$ & $60(77)$ & $44(76)$ & $71(91)$ & $16(28)$ & $8(10)$ & $36(62)$ & $59(76)$ & $50(86)$ & $50(64)$ & $41(70)$ & $52(67)$ & $56(97)$ & $70(90)$ & $7(12)$ & 14 (18) & $43(74)$ & $58(74)$ \\
\hline $\bar{P}$-value $\left(\chi^{2}\right)$ & 0.918 & 0.976 & 0.015 & 0.359 & 0.075 & 0.514 & 0.124 & 0.670 & 0.662 & 0.095 & 0.289 & 0.673 & 0.193 & 0.666 & 0.759 & 0.475 & 0.251 & 0.592 \\
\hline \multicolumn{19}{|l|}{ Differentiation } \\
\hline Well & $3(33)$ & $4(50)$ & $9(100)$ & $7(88)$ & $0(0)$ & $0(0)$ & $4(44)$ & $4(50)$ & $7(78)$ & $5(63)$ & $4(44)$ & $4(50)$ & $9(100)$ & $7(88)$ & $0(0)$ & $0(0)$ & $4(44)$ & $6(75)$ \\
\hline Moderate & $49(74)$ & $96(77)$ & $40(61)$ & 109 (88) & $27(41)$ & 17 (14) & $36(55)$ & $93(75)$ & $58(88)$ & $71(57)$ & $44(67)$ & $90(73)$ & $60(91)$ & $114(92)$ & $9(14)$ & $22(18)$ & $46(70)$ & $98(79)$ \\
\hline Poor & $15(83)$ & $16(84)$ & $13(72)$ & 18 (95) & $5(28)$ & $1(5)$ & $12(67)$ & 15 (79) & $14(78)$ & 11 (58) & $14(78)$ & $9(47)$ & $18(100)$ & $16(84)$ & $3(17)$ & $2(11)$ & $15(83)$ & 11 (58) \\
\hline$P$-value $\left(\chi^{2}\right)$ & 0.024 & 0.170 & 0.042 & 0.766 & 0.036 & 0.507 & 0.525 & 0.331 & 0.321 & 1.000 & 0.210 & 0.044 & 0.491 & 0.407 & 0.541 & 0.542 & 0.132 & 0.126 \\
\hline \multicolumn{19}{|l|}{ Primary tumor } \\
\hline $\mathrm{T} 1$ & (56) & (79) & $22(88)$ & $21(88)$ & $4(16)$ & $3(13)$ & 15( & $20(83)$ & , & 5) & & & & & $4(16)$ & & & $21(86)$ \\
\hline $\mathrm{T} 2$ & $37(78)$ & $58(73)$ & $29(62)$ & $71(89)$ & $19(40)$ & $10(13)$ & $27(57)$ & 54 (68) & 39 (83) & $40(50)$ & $33(70)$ & $52(65)$ & $43(92)$ & $70(88)$ & 7 (15) & 12 (15) & $32(68)$ & $56(70)$ \\
\hline T3 & $14(88)$ & $29(83)$ & $7(44)$ & 31 (89) & $8(50)$ & 4 (11) & $7(44)$ & $28(80)$ & $13(81)$ & $21(60)$ & $10(63)$ & $24(69)$ & $16(100)$ & $32(91)$ & $1(6)$ & $6(17)$ & $12(75)$ & 29 (83) \\
\hline $\mathrm{T} 4$ & $2(40)$ & $10(83)$ & $4(80)$ & $11(92)$ & $1(20)$ & $1(8)$ & $3(60)$ & $10(83)$ & 41 & $8(67)$ & $2(40)$ & $9(67)$ & $5(100)$ & $12(100)$ & $0(0)$ & $0(0)$ & $4(80)$ & $9(75)$ \\
\hline$P$-value $\left(\chi^{2}\right)$ & 0.030 & 0.660 & 0.015 & 1.000 & 0.070 & 1.000 & 0.753 & 0.297 & 0.623 & 0.148 & 0.585 & 0.640 & 0.804 & 0.534 & 0.850 & 0.289 & 0.965 & 0.263 \\
\hline \multicolumn{19}{|l|}{ Regional LN } \\
\hline No & $31(67)$ & $70(78)$ & $34(74)$ & 80 (89) & $14(30)$ & $13(14)$ & $25(54)$ & 66 (73) & $39(85)$ & $47(52)$ & $31(76)$ & $64(71)$ & $42(91)$ & $80(89)$ & $7(15)$ & 15 & $32(70)$ & $68(76)$ \\
\hline N1 & $12(82)$ & 31 (84) & $13(77)$ & 33 (89) & $5(29)$ & 4 (11) & $12(71)$ & $30(81)$ & $14(82)$ & $24(65)$ & $12(71)$ & $24(65)$ & 17 (100) & 35 (95) & $1(6)$ & 5 (14) & $13(77)$ & $29(78)$ \\
\hline N2 & $22(73)$ & 15 (63) & $15(50)$ & $21(88)$ & $13(43)$ & $1(4)$ & $15(50)$ & $16(67)$ & $16(87)$ & $16(67)$ & 19 (63) & 15 (63) & $28(93)$ & $22(92)$ & $4(13)$ & $4(17)$ & $20(67)$ & $18(75)$ \\
\hline$P$-value $\left(\chi^{2}\right)$ & 0.531 & 0.148 & 0.062 & 1.000 & 0.456 & 0.459 & 0.376 & 0.436 & 0.923 & 0.263 & 0.870 & 0.637 & 0.650 & 0.679 & 0.658 & 0.905 & 0.779 & 0.934 \\
\hline \multicolumn{19}{|c|}{ Distant metastasis } \\
\hline Mo & $65(72)$ & $116(77)$ & $61(60)$ & 134 (89) & $30(33)$ & $18(12)$ & $51(57)$ & $112(74)$ & $76(84)$ & 87 (58) & $60(67)$ & $103(68)$ & $84(93)$ & 137 (91) & $12(13)$ & $24(16)$ & $63(70)$ & $115(76)$ \\
\hline M1a & $2(67)$ & $0(0)$ & 1 (33) & $0(0)$ & $2(67)$ & $0(0)$ & $1(33)$ & $0(0)$ & $3(100)$ & $0(0)$ & $2(67)$ & $0(0)$ & $3(100)$ & $0(0)$ & $0(0)$ & $0(0)$ & $2(67)$ & $0(0)$ \\
\hline$P$-value $\left(\chi^{2}\right)$ & 0.631 & a & 0.257 & a & 0.271 & a & 0.411 & a & 0.609 & a & 0.709 & a & 0.817 & a & 0.657 & a & 0.663 & a \\
\hline \multicolumn{19}{|l|}{ Pathologic stage } \\
\hline I & $24(67)$ & $40(78)$ & $29(81)$ & $45(88)$ & $9(25)$ & $9(18)$ & $22(61)$ & $36(71)$ & 33 (92) & $25(49)$ & 25 (69) & 35 (69) & $33(92)$ & $46(90)$ & $6(17)$ & $11(22)$ & 25 (69) & $38(75)$ \\
\hline II & $15(75)$ & $43(77)$ & $13(65)$ & 49 (87.5) & $8(40)$ & 7 (13) & $10(50)$ & $42(75)$ & $14(70)$ & $34(61)$ & $13(65)$ & $40(71)$ & $19(95)$ & 49 (88) & $2(10)$ & $8(14)$ & $14(70)$ & $42(75)$ \\
\hline III & $26(77)$ & $33(75)$ & $19(56)$ & $40(91)$ & $13(38)$ & $2(5)$ & $19(56)$ & $34(77)$ & $29(85)$ & $28(64)$ & $22(65)$ & $28(64)$ & $32(94)$ & $42(96)$ & $4(12)$ & $5(11)$ & $24(71)$ & 35 (80) \\
\hline IV & $2(67)$ & $0(0)$ & $1(33)$ & $0(0)$ & $2(67)$ & $0(0)$ & $1(33)$ & $0(0)$ & $3(100)$ & $0(0)$ & $2(67)$ & $0(0)$ & $3(100)$ & $0(0)$ & $0(0)$ & $0(0)$ & 2 (67) & $0(0)$ \\
\hline$P$-value $\left(\chi^{2}\right)$ & 0.787 & 0.925 & 0.073 & 0.899 & 0.300 & 0.143 & 0.721 & 0.747 & 0.195 & 0.299 & 0.946 & 0.706 & 1.000 & 0.385 & 0.859 & 0.366 & 1.000 & 0.820 \\
\hline
\end{tabular}

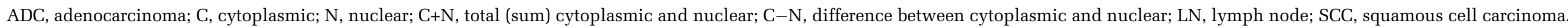
${ }^{a}$ No statistics are computed because distant metastasis in SCC is a constant.

Bold values are statistically significant. 

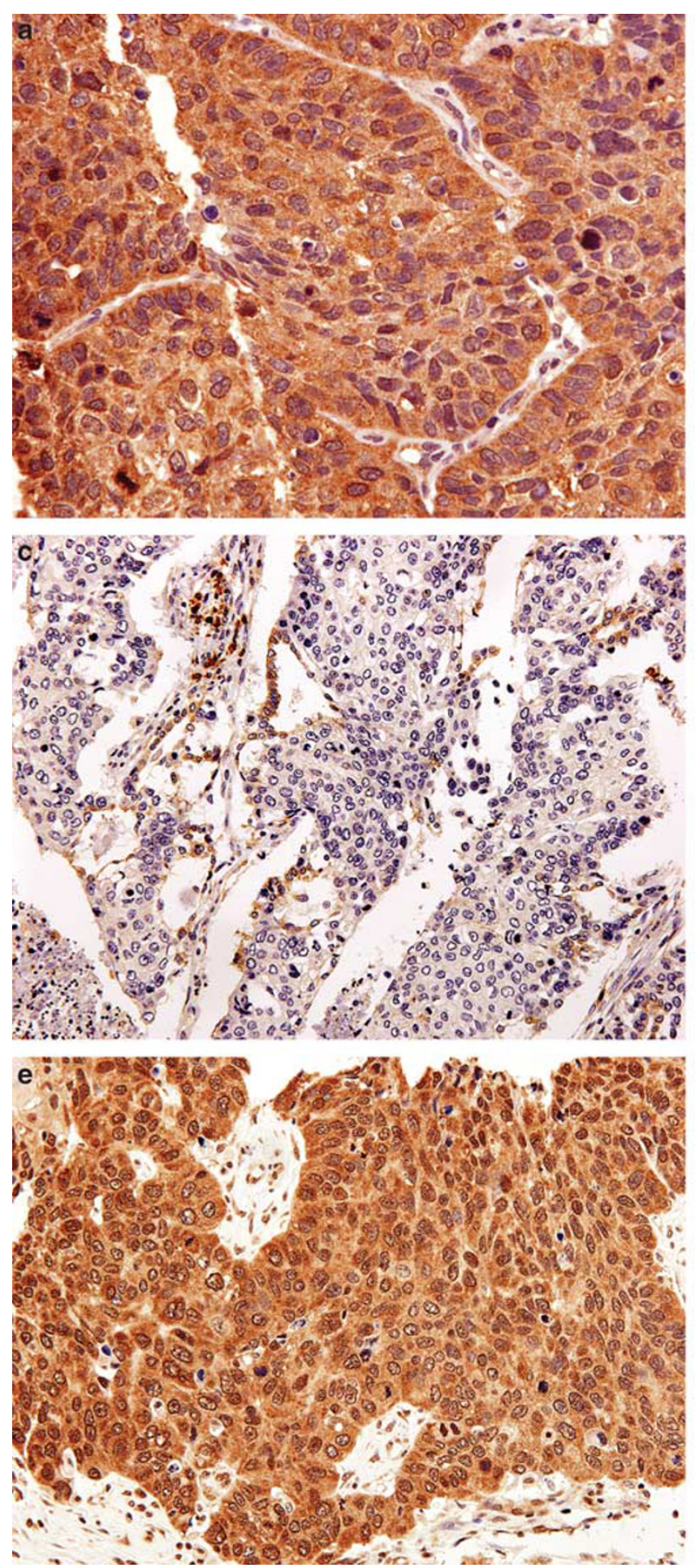
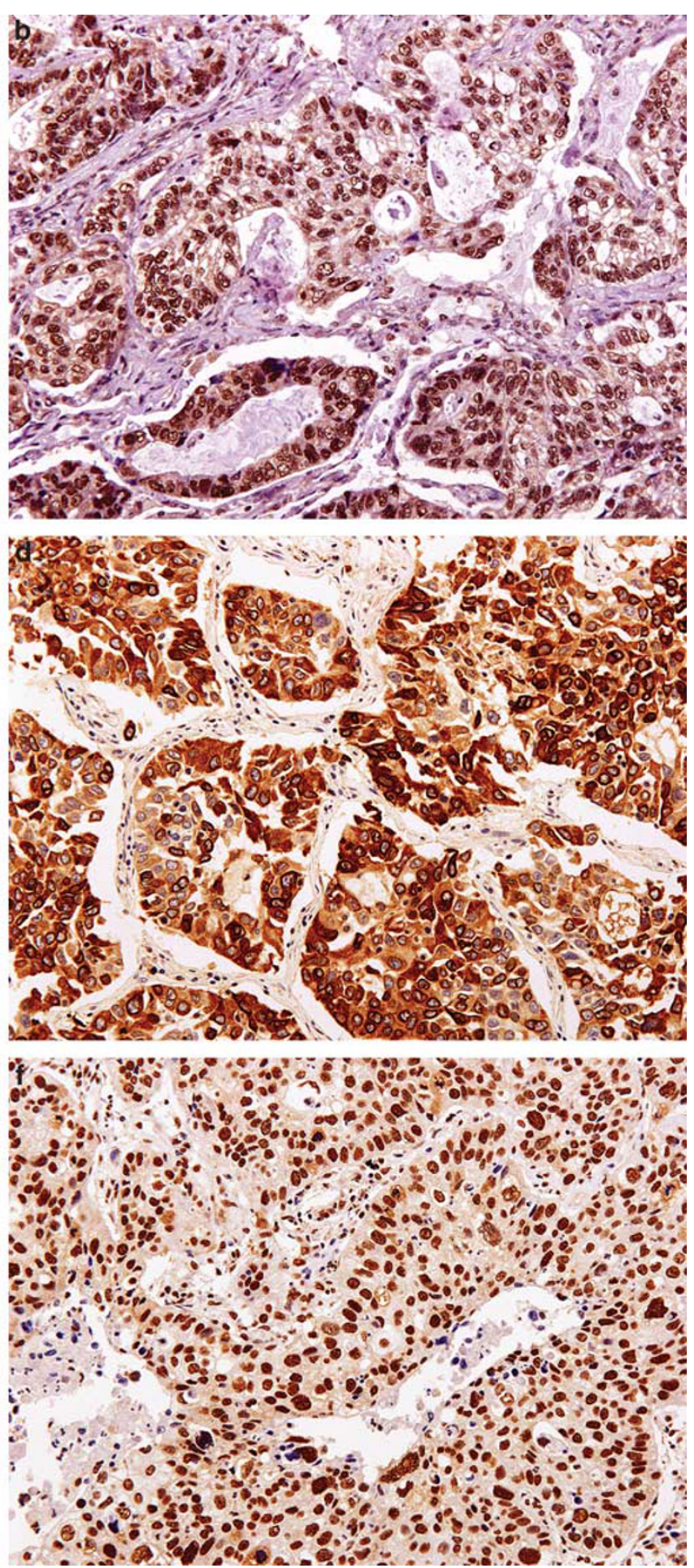

Figure 2 Immunohistochemical staining of survivin, COX-2, and HuR in non-small cell lung carcinomas. (a) Cytoplasmic survivin expression. (b) Nuclear survivin expression. (c) Negative expression of COX-2. (d) Positive expression of COX-2. (e) Cytoplasmic HuR expression. (f) Nuclear HuR expression. (Polymer method, a, $\times 400$; b to f, $\times 200$ ).

carcinoma, $P=0.015$ ) and COX-2 (squamous cell carcinoma, $P=0.020$ ) levels were determined as independent prognostic factors, along with primary tumor (T1-T2 vs T3-T4) (adenocarcinoma, $P<0.001$; squamous cell carcinoma, $P=0.002$; Table 5).

\section{Discussion}

HuR is predominantly present in the nucleus where it can bind to target mRNAs; in the cytoplasm, it stabilizes these messages. ${ }^{2}$ HuR can stabilize COX-2 mRNA, leading to an increase in COX-2 expression. ${ }^{3}$ 
Table 3 Spearman's bivariate correlations of expression between COX-2 and survivin, or HuR in 93 ADCs and 151 SCCs of the lung

\begin{tabular}{|c|c|c|c|c|}
\hline & \multicolumn{4}{|c|}{$C O X-2$} \\
\hline & \multicolumn{2}{|c|}{$A D C$} & \multicolumn{2}{|c|}{$S C C$} \\
\hline & $\rho($ rho) & $\mathrm{P}$-value & $\rho($ rho) & $\mathrm{P}$-value \\
\hline \multicolumn{5}{|c|}{ Survivin } \\
\hline C & 0.006 & 0.956 & 0.069 & 0.401 \\
\hline $\mathrm{N}$ & 0.021 & 0.840 & $-0.221^{\mathrm{a}}$ & 0.006 \\
\hline $\mathrm{C}-\mathrm{N}$ & -0.012 & 0.912 & $0.223^{\mathrm{a}}$ & 0.004 \\
\hline $\mathrm{C}+\mathrm{N}$ & -0.010 & 0.921 & -0.047 & 0.568 \\
\hline \multicolumn{5}{|l|}{ HuR } \\
\hline C & 0.085 & 0.418 & $0.192^{\mathrm{b}}$ & 0.018 \\
\hline $\mathrm{N}$ & 0.012 & 0.910 & 0.049 & 0.548 \\
\hline $\mathrm{C}-\mathrm{N}$ & 0.072 & 0.491 & $0.190^{\mathrm{b}}$ & 0.020 \\
\hline $\mathrm{C}+\mathrm{N}$ & 0.117 & 0.264 & $0.212^{\mathrm{a}}$ & 0.009 \\
\hline
\end{tabular}

ADC, adenocarcinoma; C, cytoplasmic; N, nuclear; $\mathrm{C}+\mathrm{N}$, total (sum) cytoplasmic and nuclear; $\mathrm{C}-\mathrm{N}$, difference between cytoplasmic and nuclear; SCC, squamous cell carcinoma.

${ }^{\mathrm{a}}$ Correlation is significant at the 0.01 level (two-tailed).

${ }^{\mathrm{b}}$ Correlation is significant at the 0.05 level (two-tailed).

Bold values are statistically significant.

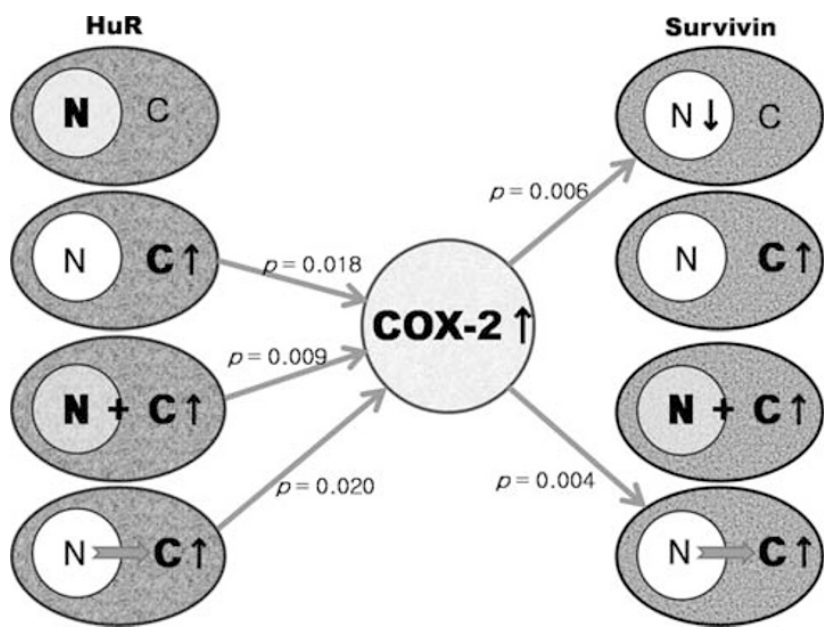

Figure 3 Correlations of HuR vs COX-2, and COX-2 vs survivin expression in 151 squamous cell carcinomas of the lung. Cytoplasmic $\operatorname{HuR}(\rho=0.192, P=0.018)$, total $\operatorname{HuR}(\rho=0.212$, $P=0.009)$, and difference of $\operatorname{HuR}(\rho=0.190, P=0.020)$ were positively correlated with COX-2 expression. COX-2 expression was positively correlated with survivin difference $(\rho=0.223$, $P=0.004)$, and inversely correlated with nuclear survivin $(\rho=-0.221, P=0.006)$.

There have been some reports showing that the constitutive overexpression of COX-2 in ovarian and colon cancers is the result of HuR overexpression, and that this process has an important role in the carcinogenesis of several cancers. ${ }^{3,4}$ A recent study reported that COX-2 expression is involved in COX-2 mRNA stabilization through HuR subcellular localization, and HuR abundance in a human lung epithelial cancer cell line, H460. ${ }^{34}$ However, HuR expression related to COX-2 expression, and prognosis in primary human lung cancers has not been explored. In this study, we did not observe any significant correlations between HuR expression and pathologic stage, or survival. Our results did show that cytoplasmic $\operatorname{HuR}(\rho=0.192, P=0.018)$, the difference in HuR (cytoplasmic - nuclear; $\rho=0.190, P=0.020$ ), and total HuR (cytoplasmic + nuclear; $\rho=0.212, P=0.009)$ were positively correlated with COX-2 expression in squamous cell carcinomas. These results suggest that increased expression of cytoplasmic HuR, independent of nuclear HuR levels, might contribute to the stabilization of COX-2 mRNA in squamous cell carcinomas of the lung. Furthermore, our study supports the suggestion that COX-2 could be a potential target of the mRNA-stabilizing activity of HuR, resulting in COX-2 overexpression. ${ }^{4,35-39}$

Elevated tumor COX-2 expression is associated with increased angiogenesis, tumor invasion, and promotion of tumor cell resistance to apoptosis. High level constitutive COX-2 expression has been detected in a variety of different malignancies, including lung cancers. $^{7-10}$ Non-steroidal antiinflammatory drugs (NSAIDS), as well as specific COX-2 inhibitors, increase the susceptibility of cancer cells to apoptosis, and therefore, have been suggested both for cancer chemoprevention and therapy. ${ }^{40}$ Previous studies have shown that COX-2 and its metabolite $\mathrm{PGE}_{2}$ promote cancer cell survival. ${ }^{41}$ COX-2 overexpression leads to survivin stabilization through decreased proteosomal degradation, thereby rendering the cancer cells more resistant to apoptotic stimuli. ${ }^{12}$ The current results showed that increased COX-2 expression in squamous cell carcinomas was associated with shorter survival rate (log rank $P=0.001$ ), and provide evidence for the importance of COX-2 overexpression in the regulation of anti-apoptotic proteins and lung cancer cell survival.

Survivin is overexpressed in several tumor types (including lung cancers) at both the protein and mRNA levels. ${ }^{13}$ There is recent evidence that subcellular localization of survivin to the nuclear and cytoplasmic pools may also correlate with prognosis. ${ }^{14}$ Nuclear and cytoplasmic pools of survivin have their distinct roles. Two functionally divergent splice variants of survivin have been indentified, survivin-2B and survivin- $\Delta \mathrm{Ex} 3{ }^{42}$ Survivin- $\Delta \mathrm{Ex} 3$ is found preferentially in the nucleus, whereas the wild type survivin and survivin-2B isoforms are localized in the cytoplasm. In the nucleus, survivin interacts with auroral B kinase and inner centromere protein (INCENP), and has a key role in completing mitosis. In the cytoplasm, survivin inhibits apoptosis by blocking caspase. It has been proposed that the nuclear pool of survivin is involved in promoting cell proliferation, whereas the cytoplasmic pool of survivin may participate in controlling cell survival, but not cell proliferation. ${ }^{42,43}$ Recent evidence shows that the direct interaction of survivin with the nuclear export receptor Crm1 is critically involved in its intracellular localization and cancer-relevant 
Table 4 Univariate analysis of the relationship between preoperative characteristics and survival in 93 ADCs and 151 SCCs of the lung

\begin{tabular}{|c|c|c|c|c|c|c|c|c|}
\hline \multirow[t]{2}{*}{ Characteristics } & \multicolumn{2}{|c|}{ No. of events (\%) } & \multicolumn{2}{|c|}{ Cumulative 5-year survival \% } & \multicolumn{2}{|c|}{ Median survival time $(\mathrm{mo}) \pm$ s.e. } & \multicolumn{2}{|c|}{ Log-rank (P-value) } \\
\hline & $A D C$ & $S C C$ & $A D C$ & $S C C$ & $A D C$ & $S C C$ & $A D C$ & $S C C$ \\
\hline Overall & $52(56)$ & $83(55)$ & 50.3 & 64.0 & $53 \pm 7.0$ & $84 \pm 23.3$ & & \\
\hline \multicolumn{9}{|l|}{ Survivin } \\
\hline $\mathrm{C}$, low & $5(19)$ & $16(45)$ & 79.3 & 73.6 & $210 \pm 24.6$ & $181 \pm 41.2$ & $<\mathbf{0 . 0 0 1}$ & 0.005 \\
\hline C, high & $47(70)$ & $67(57)$ & 32.4 & 48.7 & $43 \pm 3.9$ & $48 \pm 16.1$ & & \\
\hline $\mathrm{N}$, low & $25(81)$ & $11(65)$ & 22.9 & 28.9 & $37 \pm 6.8$ & $27 \pm 6.4$ & 0.006 & 0.050 \\
\hline $\mathrm{N}$, high & $27(44)$ & $72(54)$ & 57.1 & 58.3 & $106 \pm 52.6$ & $91 \pm 24.6$ & & \\
\hline $\mathrm{C}-\mathrm{N} \leq 0$ & $25(41)$ & $71(53)$ & 58.5 & 59.3 & $161 \pm 60.8$ & $97 \pm 24.0$ & $<\mathbf{0 . 0 0 1}$ & 0.014 \\
\hline $\mathrm{C}-\mathrm{N}>0$ & $27(84)$ & $12(67)$ & 21.4 & 21.7 & $32 \pm 6.6$ & $37 \pm 9.2$ & & \\
\hline $\mathrm{C}+\mathrm{N}<12$ & $25(41)$ & $21(54)$ & 39.4 & 60.4 & $46 \pm 4.4$ & $173 \pm 52.3$ & 0.902 & 0.171 \\
\hline $\mathrm{C}+\mathrm{N} \geq 12$ & $27(52)$ & $62(55)$ & 48.0 & 53.3 & $58 \pm 36.1$ & $66 \pm 20.6$ & & \\
\hline \multicolumn{9}{|l|}{$C O X-2$} \\
\hline Negative & $8(57)$ & $29(45)$ & 56.3 & 69.7 & $195 \pm 185.0$ & $181 \pm 64.4$ & 0.229 & 0.001 \\
\hline Positive & $44(56)$ & $54(62)$ & 40.6 & 44.0 & $45 \pm 5.9$ & $39 \pm 7.4$ & & \\
\hline \multicolumn{9}{|l|}{$\mathrm{HuR}$} \\
\hline $\mathrm{C}$, low & $14(45)$ & $28(58)$ & 48.2 & 49.8 & $58 \pm 24.1$ & $48 \pm 33.2$ & 0.207 & 0.580 \\
\hline C, high & $38(61)$ & $55(53)$ & 41.7 & 57.9 & $46 \pm 5.0$ & $91 \pm 24.7$ & & \\
\hline $\mathrm{N}$, low & 4 (67) & 8 (57) & 66.7 & 50.0 & $66 \pm 52.7$ & $20 \pm 39.8$ & 0.789 & 0.616 \\
\hline $\mathrm{N}$, high & $48(55)$ & $75(55)$ & 41.5 & 55.6 & $46 \pm 5.5$ & $85 \pm 25.0$ & & \\
\hline $\mathrm{C}-\mathrm{N} \leq 0$ & $44(54)$ & $71(56)$ & 44.4 & 57.1 & $46 \pm 8.6$ & $80 \pm 28.1$ & 0.769 & 0.809 \\
\hline $\mathrm{C}-\mathrm{N}>0$ & $8(67)$ & $12(50)$ & 42.3 & 60.4 & $54 \pm 9.7$ & $85 \pm 27.6$ & & \\
\hline $\mathrm{C}+\mathrm{N}<12$ & $14(50)$ & $19(53)$ & 54.8 & 54.5 & $66 \pm 44.6$ & $62 \pm 43.5$ & 0.192 & 0.942 \\
\hline $\mathrm{C}+\mathrm{N} \geq 12$ & $38(58)$ & $51(56)$ & 38.7 & 55.3 & $46 \pm 4.8$ & $85 \pm 25.8$ & & \\
\hline \multicolumn{9}{|l|}{ Gender } \\
\hline Female & $23(58)$ & $9(60)$ & 41.7 & 42.9 & $45 \pm 8.3$ & $25 \pm 19.6$ & 0.761 & 0.774 \\
\hline Male & $29(55)$ & $74(54)$ & 45.3 & 56.6 & $54 \pm 12.2$ & $92 \pm 19.6$ & & \\
\hline \multicolumn{9}{|l|}{ Age } \\
\hline$<62$ & $23(66)$ & $40(55)$ & 31.9 & 59.6 & $44 \pm 2.6$ & $106 \pm 30.3$ & 0.390 & 0.434 \\
\hline$\geq 62$ & $29(50)$ & $43(55)$ & 52.7 & 50.6 & $97 \pm 39.9$ & $66 \pm 22.0$ & & \\
\hline \multicolumn{9}{|l|}{ Differentiation } \\
\hline W-M & $40(53)$ & $73(55)$ & 45.9 & 57.3 & $54 \pm 11.9$ & $97 \pm 22.1$ & 0.181 & 0.408 \\
\hline Poor & $12(67)$ & $10(56)$ & 36.4 & 38.1 & $43 \pm 9.6$ & $38 \pm 15.6$ & & \\
\hline \multicolumn{9}{|l|}{ Primary tumor } \\
\hline $\mathrm{T} 1-\mathrm{T} 2$ & $36(50)$ & $50(48)$ & 52.3 & 63.0 & $72 \pm 29.5$ & $136 \pm 49.9$ & $<0.001$ & 0.001 \\
\hline $\mathrm{T} 3-\mathrm{T} 4$ & $16(76)$ & $33(70)$ & 14.4 & 37.7 & $21 \pm 8.1$ & $27 \pm 8.0$ & & \\
\hline \multicolumn{9}{|l|}{ Regional LN } \\
\hline No & $22(48)$ & $41(46)$ & 62.5 & 62.6 & $97 \pm 29.4$ & $127 \pm 28.3$ & 0.040 & 0.001 \\
\hline N1-N2 & $30(64)$ & $42(69)$ & 27.3 & 44.7 & $41 \pm 3.3$ & $25 \pm 18.6$ & & \\
\hline \multicolumn{9}{|c|}{ Distant metastasis } \\
\hline Mo & $49(54)$ & $83(55)$ & 45.5 & 55.2 & $54 \pm 10.0$ & $84 \pm 23.3$ & 0.028 & a \\
\hline M1 & $3(100)$ & $0(0)$ & 0 & a & $29 \pm 6.5$ & a & & \\
\hline \multicolumn{9}{|l|}{ Pathologic stage } \\
\hline I-II & $27(48)$ & $52(49)$ & 59.2 & 63.3 & $106 \pm 46.5$ & $127 \pm 39.1$ & 0.003 & $<\mathbf{0 . 0 0 1}$ \\
\hline III-IV & $25(68)$ & $31(71)$ & 17.6 & 34.1 & $41 \pm 6.5$ & $24 \pm 4.6$ & & \\
\hline
\end{tabular}

ADC, adenocarcinoma; C, cytoplasmic; N, nuclear; $\mathrm{C}+\mathrm{N}$, total (sum) cytoplasmic and nuclear; $\mathrm{C}-\mathrm{N}$, difference between cytoplasmic and nuclear; LN, lymph node; SCC, squamous cell carcinoma; W-M, well to moderate.

${ }^{\mathrm{a}}$ No statistics are computed because distant metastasis in SCC is a constant.

Bold values are statistically significant.

functions. ${ }^{15-18}$ Nuclear export signals (NES) are leucine-rich, interact with the export receptor Crm1 in the nucleus, and depend on the RanGTP/ GDP axis, which control the Crm1/substrate interaction. ${ }^{16}$ Preferential nuclear survivin was indeed found to be a favorable predictor for various tumor types, although some reports consider nuclear survivin to be associated with poor survival. ${ }^{43-45}$ In lung cancers, several studies indicated that expression of nuclear or cytoplasmic survivin is related to poor survival. Kren et $a{ }^{26}{ }^{26}$ who evaluated only cytoplasmic survivin, identified it as a predictor of 

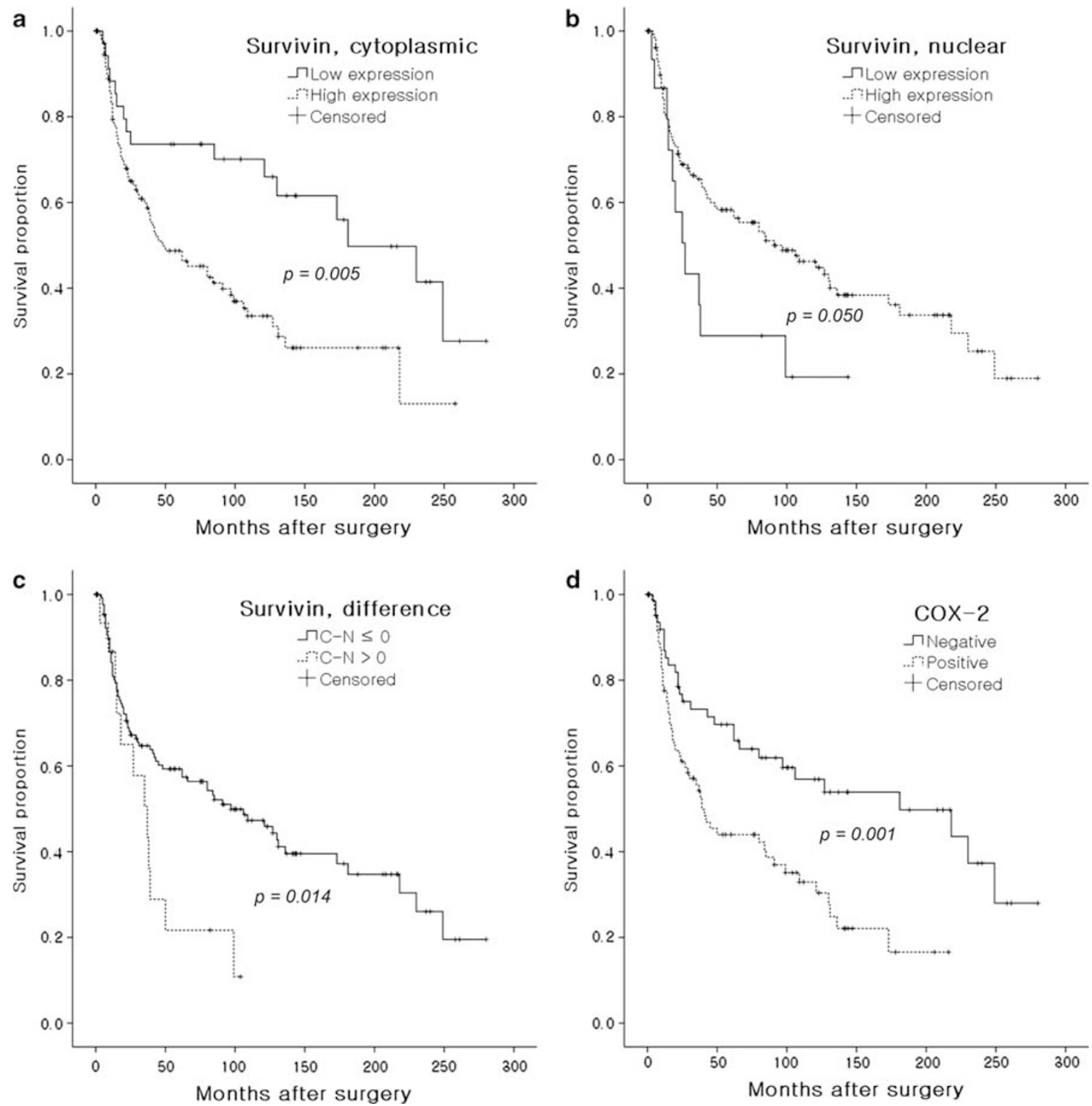

Figure 4 Kaplan-Meier survival curves showing overall survival of patients with squamous cell carcinomas of the lung. Patients are dichotomized according to the immunoreactive score. High expression of cytoplasmic survivin (a), low expression of nuclear survivin (b), difference $(\mathrm{C}-\mathrm{N}>0)$ between cytoplasmic and nuclear survivin (c), and positive COX-2 expression (d), are correlated with a shorter survival rate.

shorter survival, whereas Vischioni et $a 1^{24}$ identified nuclear survivin as a positive prognostic factor for survival. The results of this study, along with those of previous studies, on the location of survivin in cancer cells and its relation to survival and/or stage in pulmonary adenocarcinomas and squamous cell carcinomas are shown in Table 6. These seemingly contradictory findings regarding the relationship between survivin expression and prognosis may be explained in a few ways. First, the difference may be associated with the tumor types and/or the biopsies examined (pre-therapeutic vs post-therapeutic). Second, different commercial antibodies may have been used. Third, it may be due to the variable criteria used to classify a tumor as having more nuclear survivin or cytoplasmic survivin. ${ }^{24,29,46}$ As the balance between cytoplasmic and nuclear survivin in tumor cells may be considered as an indicator for 'active survivin,' it is advisable to quantify not only absolute expression levels, but also the relative intracellular localization of survivin, cytoplasmic, nuclear, total (cytoplasmic + nuclear), and the difference in survivin expression (cytoplasmic - nuclear). ${ }^{45}$ Our results showed that cytoplasmic survivin (log rank test, adenocarcinoma, $P<0.001$; squamous cell carcinoma, $P=0.005$ ) and the difference in survivin (log rank test, adenocarcinoma, $P<0.001$; squamous cell carcinoma, $P=0.014)$ was associated with a poorer survival rate, whereas nuclear survivin expression (log rank 
Table 5 COX proportional hazards model in 93 ADCs and 151 SCCs of the lung

\begin{tabular}{|c|c|c|c|c|c|}
\hline Variables & Level & Histology & OR & $95 \% C I$ & $\mathrm{P}$-value \\
\hline \multirow[t]{2}{*}{ Gender } & \multirow[t]{2}{*}{ Female vs male } & $\mathrm{ADC}$ & 0.944 & $0.500-1.784$ & 0.860 \\
\hline & & SCC & 0.618 & $0.298-1.282$ & 0.197 \\
\hline \multirow[t]{2}{*}{ Age (years) } & \multirow[t]{2}{*}{$<62$ vs $\geq 62$} & $\mathrm{ADC}$ & 0.723 & $0.394-1.327$ & 0.295 \\
\hline & & SCC & 1.186 & $0.750-1.877$ & 0.466 \\
\hline \multirow[t]{2}{*}{ Differentiation } & \multirow[t]{2}{*}{$\mathrm{W}-\mathrm{M}$ vs $\mathrm{P}$} & $\mathrm{ADC}$ & 1.622 & $0.823-3.195$ & 0.162 \\
\hline & & SCC & 1.125 & $0.550-2.301$ & 0.747 \\
\hline \multirow[t]{2}{*}{ Primary tumor } & \multirow[t]{2}{*}{$\mathrm{T} 1-\mathrm{T} 2$ vs $\mathrm{T} 3-\mathrm{T} 4$} & ADC & 3.018 & $1.628-5.598$ & $<\mathbf{0 . 0 0 1}$ \\
\hline & & SCC & 2.016 & $1.285-3.162$ & 0.002 \\
\hline \multirow[t]{2}{*}{ Regional LN } & \multirow[t]{2}{*}{ N0 vs N1-N2 } & ADC & 1.717 & $0.976-3.022$ & 0.061 \\
\hline & & SCC & 2.052 & $1.316-3.200$ & 0.002 \\
\hline \multirow[t]{2}{*}{ Distant metastasis } & \multirow[t]{2}{*}{ M0 vs M1 } & $\mathrm{ADC}$ & 1.231 & $0.332-4.566$ & 0.756 \\
\hline & & SCC & $\mathrm{a}$ & $\mathrm{a}$ & $\mathrm{a}$ \\
\hline \multirow[t]{2}{*}{ Pathologic stage } & \multirow{2}{*}{ I-II vs III-IV } & ADC & 1.183 & $0.360-3.890$ & 0.782 \\
\hline & & SCC & 1.459 & $0.758-2.809$ & 0.258 \\
\hline \multicolumn{6}{|l|}{ Survivin } \\
\hline \multirow{2}{*}{ C } & \multirow{2}{*}{ Low vs high } & $\mathrm{ADC}$ & 4.514 & $1.708-11.929$ & 0.002 \\
\hline & & SCC & 2.052 & $1.148-3.575$ & 0.015 \\
\hline \multirow[t]{2}{*}{$\mathrm{N}$} & \multirow[t]{2}{*}{ Low vs high } & $\mathrm{ADC}$ & 0.505 & $0.088-2.892$ & 0.443 \\
\hline & & SCC & 0.962 & $0.313-2.961$ & 0.947 \\
\hline \multirow[t]{2}{*}{$\mathrm{C}-\mathrm{N}$} & \multirow[t]{2}{*}{$\leq 0$ vs $>0$} & $\mathrm{ADC}$ & 1.794 & $0.994-3.239$ & 0.053 \\
\hline & & SCC & 1.702 & $0.878-3.299$ & 0.115 \\
\hline \multirow[t]{2}{*}{$\mathrm{C}+\mathrm{N}$} & \multirow[t]{2}{*}{$<12$ vs $\geq 12$} & $\mathrm{ADC}$ & 2.192 & $0.856-5.610$ & 0.102 \\
\hline & & SCC & 1.026 & $0.340-3.098$ & 0.964 \\
\hline \multirow[t]{2}{*}{ COX-2 } & \multirow[t]{2}{*}{ Low vs high } & ADC & 1.755 & $0.747-4.124$ & 0.197 \\
\hline & & SCC & 1.777 & $1.095-2.883$ & $\mathbf{0 . 0 2 0}$ \\
\hline \multicolumn{6}{|l|}{$H u R$} \\
\hline \multirow[t]{2}{*}{ C } & \multirow{2}{*}{ Low vs high } & $\mathrm{ADC}$ & 1.254 & $0.396-3.971$ & 0.700 \\
\hline & & SCC & 0.780 & $0.463-1.314$ & 0.351 \\
\hline \multirow[t]{2}{*}{$\mathrm{N}$} & Low vs high & ADC & 1.307 & $0.239-7.148$ & 0.757 \\
\hline & & SCC & 0.576 & $0.274-1.211$ & 0.146 \\
\hline $\mathrm{C}-\mathrm{N}$ & $\leq 0$ vs $>0$ & ADC & 0.678 & $0.296-1.553$ & 0.358 \\
\hline & & SCC & 0.657 & $0.344-1.254$ & 0.203 \\
\hline $\mathrm{C}+\mathrm{N}$ & $<12$ vs $\geq 12$ & $\mathrm{ADC}$ & 0.840 & $0.415-1.698$ & 0.627 \\
\hline & & SCC & 1.001 & $0.440-2.281$ & 0.998 \\
\hline
\end{tabular}

ADC, adenocarcinoma; C, cytoplasmic; N, nuclear; $\mathrm{C}+\mathrm{N}$, total (sum) cytoplasmic and nuclear; $\mathrm{C}-\mathrm{N}$, difference between cytoplasmic and nuclear; CI, confidence interval; P, poor; OR, odds ratio; SCC, squamous cell carcinoma; W-M, well to moderate.

${ }^{\mathrm{a}}$ No statistics are computed because distant metastasis in SCC is a constant.

Bold values are statistically significant.

Table 6 Nuclear and/or cytoplasmic survivin immunohistochemistry, and its relation with stage and prognosis of pulmonary ADCs and SCCs in other studies and the present study

\begin{tabular}{|c|c|c|c|c|c|}
\hline Author & Antibody & No. of cases & Stage & Survival & Year reference \\
\hline Falleni & Polyclonal NB 500-201 (ab469); Novus & 44 & $\mathrm{C},+$ & Not related & $2003^{23}$ \\
\hline Vischioni & Polyclonal NB 500-201 (ab469); Novus & 53 & - & $\mathrm{N}$, good & $2004^{24}$ \\
\hline $\mathrm{Lu}$ & Monclonal D8 (SC-17779); Santa Cruz & 48 & - & $\mathrm{N}$, poor & $2004^{25}$ \\
\hline Kren & Polyclonal goat anti-human; Santa Cruz & 102 & $\mathrm{C},+$ & C, poor & $2004^{26}$ \\
\hline Shinohara & Monclonal D8 (SC-17779); Santa Cruz & 41 & - & $\mathrm{N}$, poor & $2005^{27}$ \\
\hline Atikcan & Monoclonal 4F7; Neo Markers & 58 & Not related & $\mathrm{N}$, poor & $2006^{28}$ \\
\hline Ulukus & Monoclonal 4F7; Neo Markers & 63 & $\mathrm{~N},-$ & Not related & $2007^{29}$ \\
\hline Bria & Polyclonal (ab469); Abcam & 116 & - & $\mathrm{N}$, poor & $2008^{30}$ \\
\hline $\mathrm{He}$ & Polyclonal (ZA-0458); Zhongshan Goldenbridge & 51 & $\mathrm{C},+\mathrm{C}$ and $\mathrm{N},+$ & $\mathrm{N}$, good & $2009^{31}$ \\
\hline Present study & Polyclonal NB 500-201 (ab469); Novus & 244 & Not related & $\mathrm{N}$, good $\mathrm{C}$, poor & - \\
\hline
\end{tabular}

C, cytoplasmic immnunoreactivity; N, nuclear immunoreactivity; '+', correlated; '-’, = inversely correlated; '-', not evaluated.

test, adenocarcinoma, $P=0.006 ;$ squamous cell carcinoma, $P=0.050$ ) was associated with a favorable survival rate. Even though the above factors were not associated with a high cancer stage, these results are consistent with proposed hypothesis and findings in previous studies. ${ }^{24,26,45}$ The current data suggest that cytoplasmic and active survivin (survivin converted from nuclear to cytoplasmic) represents 'cytoprotective survivin' in tumor cells, whereas nuclear survivin may have 'impaired survivin function.'

Our results show that COX-2 expression in squamous cell carcinomas was positively correlated 
with the difference in survivin level (cytoplasmic immunoreactive score-nuclear immunoreactive score; $\rho=0.223, P=0.004$ ), and inversely correlated with nuclear survivin $(\rho=-0.221, P=0.006)$. These findings suggest that active ('dynamic') survivin exported from the nucleus to the cytoplasm through an NES/Crm1 transporter is significantly associated with increased expression of COX-2. Thus, increased expression of active cytoplasmic survivin and decreased nuclear survivin could be an indicator of the inhibition of apoptosis of tumor cells or tumor progression. Our results support the hypothesis that COX-2 overexpression and $\mathrm{PGE}_{2}$ overproduction inhibit survivin ubiquitination, which leads to its stabilization and prevents proteasomal degradation of survivin in squamous cell carcinoma cells. Our findings provide evidence for the importance of COX-2 overexpression in the regulation of antiapoptotic proteins and lung cancer cell survival. In addition, these results suggest that NES/Crm1 transporter should be pursued as a potential target of tumor therapy. To our knowledge, the present study is the first large scale study for evaluation of $\mathrm{HuR}$, COX-2, and survivin expression and its correlations in primary adenocarcinomas and squamous cell carcinomas of human lung.

In conclusion, cytoplasmic HuR expression is associated with COX-2 expression in pulmonary squamous cell carcinomas. Our study supports the suggestion that COX-2 could be a potential target of the mRNA-stabilizing activity of cytoplasmic HuR, resulting in COX-2 overexpression. Increased COX-2 expression is associated with active conversion of survivin from nuclear to cytoplasmic, and low expression of nuclear survivin, which contributes to the anti-apoptotic effect and over proliferation of pulmonary squamous cell carcinomas. The expression of COX-2 and cytoplasmic survivin in pulmonary squamous cell carcinomas is associated with poor survival rate and could be a useful, independent prognostic marker, and potential therapeutic strategy for pulmonary squamous cell carcinomas.

\section{Acknowledgement}

This work was supported by a grant from the Kyung Hee University Research Fund in 2006 (KHU20061223).

\section{Disclosure/conflict of interest}

The authors declare no conflict of interest.

\section{References}

1 Brennan CM, Steitz JA. HuR and mRNA stability. Cell Mol Life Sci 2001;58:266-277.
2 Gallouzi IE, Steitz JA. Delineation of mRNA export pathways by the use of cell-permeable peptides. Science 2001;294:1895-1901.

3 Dixon DA, Tolley ND, King $\mathrm{PH}$, et al. Altered expression of the mRNA stability factor HuR promotes cyclooxygenase-2 expression in colon cancer cells. J Clin Invest 2001;108:1657-1665.

4 Erkinheimo TL, Lassus H, Sivula A, et al. Cytoplasmic HuR expression correlates with poor outcome and with cyclooxygenase 2 expression in serous ovarian carcinoma. Cancer Res 2003;63:7591-7594.

5 Herschman HR. Prostaglandin synthase 2. Biochim Biophys Acta 1996;1299:125-140.

6 Dubois RN, Abramson SB, Crofford L, et al. Cyclooxygenase in biology and disease. FASEB J 1998;12: 1063-1073.

7 Huang M, Stolina M, Sharma S, et al. Non-small cell lung cancer cyclooxygenase-2-dependent regulation of cytokine balance in lymphocytes and macrophages: up-regulation of interleukin 10 and down-regulation of interleukin 12 production. Cancer Res 1998;58: 1208-1216.

8 Wolff H, Saukkonen K, Anttila S, et al. Expression of cyclooxygenase-2 in human lung carcinoma. Cancer Res 1998;58:4997-5001.

9 Soslow RA, Dannenberg AJ, Rush D, et al. COX-2 is expressed in human pulmonary, colonic, and mammary tumors. Cancer 2000;89:2637-2645.

10 Khuri FR, Wu H, Lee JJ, et al. Cyclooxygenase-2 overexpression is a marker of poor prognosis in stage I non-small cell lung cancer. Clin Cancer Res 2001;7: 861-867.

11 Dohadwala M, Luo J, Zhu L, et al. Non-small cell lung cancer cyclooxygenase-2-dependent invasion is mediated by CD44. J Biol Chem 2001;276: 20809-20812.

12 Krysan K, Merchant FH, Zhu L, et al. COX-2dependent stabilization of survivin in non-small cell lung cancer. FASEB J 2004;18:206-208.

13 Ambrosini G, Adida C, Altieri DC. A novel anti-apoptosis gene, survivin, expressed in cancer and lymphoma. Nat Med 1997;3:917-921.

14 Fortugno P, Wall NR, Giodini A, et al. Survivin exists in immunochemically distinct subcellular pools and is involved in spindle microtubule function. J Cell Sci 2002;115:575-585.

15 Rodriguez JA, Span SW, Ferreira CG, et al. CRM1mediated nuclear export determines the cytoplasmic localization of the antiapoptotic protein Survivin. Exp Cell Res 2002;275:44-53.

16 Weis K. Regulating access to the genome: nucleocytoplasmic transport throughout the cell cycle. Cell 2003; 112:441-451.

17 Rodriguez JA, Lens SM, Span SW, et al. Subcellular localization and nucleocytoplasmic transport of the chromosomal passenger proteins before nuclear envelope breakdown. Oncogene 2006;25: 4867-4879.

18 Knauer SK, Bier C, Habtemichael N, et al. The Survivin-Crm1 interaction is essential for chromosomal passenger complex localization and function. EMBO Rep 2006;7:1259-1265.

19 Li F, Ambrosini G, Chu EY, et al. Control of apoptosis and mitotic spindle checkpoint by survivin. Nature 1998;396:580-584.

20 Reed JC. The Survivin saga goes in vivo. J Clin Invest 2001;108:965-969. 
21 Pennati M, Folini M, Zaffaroni N. Targeting survivin in cancer therapy. Expert Opin Ther Targets 2008;12: 463-476.

22 Krysan K, Dalwadi H, Sharma S, et al. Cyclooxygenase 2-dependent expression of survivin is critical for apoptosis resistance in non-small cell lung cancer. Cancer Res 2004;64:6359-6362.

23 Falleni M, Pellegrini C, Marchetti A, et al. Survivin gene expression in early-stage non-small cell lung cancer. J Pathol 2003;200:620-626.

24 Vischioni B, van der Valk P, Span SW, et al. Nuclear localization of survivin is a positive prognostic factor for survival in advanced non-small-cell lung cancer. Ann Oncol 2004;15:1654-1660.

$25 \mathrm{Lu}$ B, Gonzalez A, Massion PP, et al. Nuclear survivin as a biomarker for non-small-cell lung cancer. Br J Cancer 2004;91:537-540.

26 Kren L, Brazdil J, Hermanova M, et al. Prognostic significance of anti-apoptosis proteins survivin and bcl-2 in non-small cell lung carcinomas: a clinicopathologic study of 102 cases. Appl Immunohistochem Mol Morphol 2004;12:44-49.

27 Shinohara ET, Gonzalez A, Massion PP, et al. Nuclear survivin predicts recurrence and poor survival in patients with resected nonsmall cell lung carcinoma. Cancer 2005;103:1685-1692.

28 Atikcan S, Unsal E, Demirag F, et al. Correlation between survivin expression and prognosis in nonsmall cell lung cancer. Respir Med 2006;100: 2220-2226.

29 Ulukus EC, Kargi HA, Sis B, et al. Survivin expression in non-small-cell lung carcinomas: correlation with apoptosis and other apoptosis-related proteins, clinicopathologic prognostic factors and prognosis. Appl Immunohistochem Mol Morphol 2007;15: 31-37.

30 Bria E, Visca P, Novelli F, et al. Nuclear and cytoplasmic cellular distribution of survivin as survival predictor in resected non-small-cell lung cancer. Eur J Surg Oncol 2008;34:593-598.

31 He L, Hou M, Zhang J, et al. Subcellular localization of survivin in non-small cell lung cancer]. Chinese J Cancer 2009;28:955-960.

32 Travis WD, World Health Organization, International Agency for Research on Cancer, International Association for the Study of Lung Cancer, International Academy of Pathology. Pathology and genetics of tumours of the lung, pleura, thymus and heart. IARC Press: Lyon, 2004.

33 Edge SB, American Joint Committee on Cancer, American Cancer Society. AJCC Cancer Staging Manual 7th edn, Springer: New York, 2010.
34 Xiao J, Tan Y, Pan Y, et al. A new cyclooxygenase-2 inhibitor, (1E,4E)-1,5-bis(2-bromophenyl)penta-1, 4-dien-3-one (GL63) suppresses cyclooxygenase-2 gene expression in human lung epithelial cancer cells: coupled mRNA stabilization and posttranscriptional inhibition. Biol Pharm Bull 2010;33:1170-1175.

35 Sengupta S, Jang BC, Wu MT, et al. The RNA-binding protein HuR regulates the expression of cyclooxygenase-2. J Biol Chem 2003;278:25227-25233.

36 Denkert C, Weichert W, Pest S, et al. Overexpression of the embryonic-lethal abnormal vision-like protein HuR in ovarian carcinoma is a prognostic factor and is associated with increased cyclooxygenase 2 expression. Cancer Res 2004;64:189-195.

37 Denkert C, Weichert W, Winzer KJ, et al. Expression of the ELAV-like protein HuR is associated with higher tumor grade and increased cyclooxygenase-2 expression in human breast carcinoma. Clin Cancer Res 2004;10:5580-5586.

38 Mrena J, Wiksten JP, Thiel A, et al. Cyclooxygenase-2 is an independent prognostic factor in gastric cancer and its expression is regulated by the messenger RNA stability factor HuR. Clin Cancer Res 2005;11: 7362-7368.

39 Denkert C, Koch I, von Keyserlingk N, et al. Expression of the ELAV-like protein HuR in human colon cancer: association with tumor stage and cyclooxygenase-2. Mod Pathol 2006;19:1261-1269.

40 Turini ME, DuBois RN. Cyclooxygenase-2: a therapeutic target. Annu Rev Med 2002;53:35-57.

41 Sheng H, Shao J, Morrow JD, et al. Modulation of apoptosis and Bcl-2 expression by prostaglandin E2 in human colon cancer cells. Cancer Res 1998;58: 362-366.

42 Mahotka C, Wenzel M, Springer E, et al. SurvivindeltaEx3 and survivin-2B: two novel splice variants of the apoptosis inhibitor survivin with different antiapoptotic properties. Cancer Res 1999;59:6097-6102.

43 Li F, Yang J, Ramnath N, et al. Nuclear or cytoplasmic expression of survivin: what is the significance? Int J Cancer 2005;114:509-512.

44 Knauer SK, Kramer OH, Knosel T, et al. Nuclear export is essential for the tumor-promoting activity of survivin. FASEB J 2007;21:207-216.

45 Engels K, Knauer SK, Metzler D, et al. Dynamic intracellular survivin in oral squamous cell carcinoma: underlying molecular mechanism and potential as an early prognostic marker. J Pathol 2007;211:532-540.

46 Vischioni B, Oudejans JJ, Kruyt FA, et al. Immunohistochemical detection of nuclear survivin in NSCLC: a comparison of commercial antibodies. Histopathology 2007;50:671-675. 